\title{
ZONED TUNGSTENOAN MOLYBDENITE FROM A FENITIZED MEGAXENOLITH IN THE KHIBINA ALKALINE COMPLEX, KOLA PENINSULA, RUSSIA
}

\author{
ANDREI Y. BARKOV§, ROBERT F. MARTIN AND GLENN POIRIER \\ Department of Earth and Planetary Sciences, McGill University, 3450 University Street, Montreal, Quebec H3A 2A7, Canada
}

YURI P. MEN'SHIKOV

Geological Institute, Kola Science Center, Russian Academy of Sciences, 14 Fersman Street, 184200 Apatity, Russia

\begin{abstract}
Zoned tungstenoan molybdenite occurs in a fenite ( $~ 80$ modal \% nepheline) within a strongly heterogeneous fenitized megaxenolith $(\sim 0.2 \mathrm{~km})$ enclosed by nepheline syenite, in the Khibina alkaline complex, Kola Peninsula, Russia. Molybdenite forms euhedral crystals $(\sim 50-60 \mu \mathrm{m}$ in length), enclosed by pyrrhotite, and abundant veinlets among silicates. The crystals are zoned with respect to tungsten, which is strongly enriched in the central zone. This area is 5-6 $\mu \mathrm{m}$ across and contains up to 5.85 wt. $\% \mathrm{~W}(0.05$ atoms per formula unit). Tungsten-rich zones of the molybdenite veinlets contain the same concentration of $\mathrm{W}$ as the central zone of the euhedral crystals, implying similar conditions of formation. There is thus a substantial solid-solution between molybdenite and tungstenite. We attribute the outward zoning to W-poor molybdenite in terms of increasing fugacity of oxygen and decreasing fugacity of sulfur, apparently in the presence of a reduced $\mathrm{H}_{2} \mathrm{~S}-\mathrm{CH}_{4}$-rich fluid of subalkaline character. The existence of locally reducing conditions in the fenite(s) at Khibina also is implied by the adjacent occurrences of titaniumand niobium-rich sulfides and a graphite-like material.
\end{abstract}

Keywords: tungsten, molybdenite, molybdenite-tungstenite series, zoning, fenite, xenolith, alkaline complex, Khibina, Kola Peninsula, Russia.

\section{SoMmaIRE}

Nous décrivons des cristaux de molybdénite zonés en tungstène provenant d'une fénite ( $80 \%$ de néphéline) prélevée d'un mégaxénolithe $(\sim 0.2 \mathrm{~km})$ fénitisé fortement hétérogène inclus dans une syénite néphélinique du complexe alcalin de Khibina, dans la péninsule de Kola, en Russie. La molybdénite se présente en cristaux idiomorphes ( $50-60 \mu \mathrm{m}$ in length) inclus dans la pyrrhotite, et en veinules filamenteuses parmi les silicates. Les cristaux sont zonés par rapport au tungstène, qui est enrichi dans le coeur des cristaux; cette zone, 5-6 $\mu \mathrm{m}$ en largeur, atteint $5.85 \% \mathrm{~W}$ en poids ( 0.05 atomes par unité formulaire). Les zones riches en tungstène des veinules de molybdénite contiennent la même concentration de $\mathrm{W}$ que la zone centrale des cristaux idiomorphes, témoignant ainsi de conditions semblables de formation. Il y a donc une solution solide substantielle entre molybdénite et tungstenite. Nous attribuons le passage à une molybdénite banale sans $\mathrm{W}$ en direction de la bordure des grains en termes d'une augmentation de la fugacité d'oxygène et d'une diminution de la fugacité de soufre, apparemment en présence d'une phase fluide subalcaline réductrice contenant $\mathrm{H}_{2} \mathrm{~S}$ et $\mathrm{CH}_{4}$. L'existence de telles conditions reductrices à l'échelle locale dans les fénites de Khibina concorderait avec le développement de sulfures contenant titane et niobium et d'un matériau ressemblant au graphite.

(Traduit par la Rédaction)

Mots-clés: tungstène, molybdénite, série molybdénite-tungstenite, zonation, fénite, xénolithe, complexe alcalin, Khibina, péninsule de Kola, Russie.

§ E-mail address: barkov@eps.mcgill.ca 


\section{INTRODUCTION}

Molybdenite, the most common mineral of molybdenum, is found in many terrestrial environments and in meteorites. Almost invariably, it is very close to the end-member composition, $\mathrm{MoS}_{2}$. Significant concentrations of rhenium (up to $11.5 \mathrm{wt} . \%$ ) have been reported in molybdenite (Kovalenker et al. 1974, Bernard et al. 1990). On the other hand, tungsten, where present, is incorporated as a trace constituent, regardless of the common coexistence of molybdenite with $\mathrm{W}$-bearing minerals. In this paper, we report an unusual occurrence of tungstenoan molybdenite from the Khibina alkaline complex, Kola Peninsula, northwestern Russia. We attempt to identify the geochemical environment that promoted the structural incorporation of significant quantities of tungsten in molybdenite.

\section{BACKGROUND INFORMATION}

Both molybdenum and tungsten exhibit two valence states in the Earth's crust, although the two elements are distinct in their pattern of distribution, as initially recognized by Goldschmidt (1954). Molybdenum exhibits a mixed chalcophile-lithophile character. Molybdenite is by far the main expression of the reduced form (i.e., $\mathrm{Mo}^{4+}$ ), whereas molybdates and other oxysalts of $\mathrm{Mo}^{6+}$ form in zones of secondary oxidation of molybdenite-bearing ore deposits. In addition to rare occurrences of tungstenite $\left(\mathrm{WS}_{2}\right), \mathrm{W}^{4+}$ also presumably occurs in kiddcreekite $\mathrm{Cu}_{6} \mathrm{WSnS}_{8}$ (Harris et al. 1984, Zhang \& Zhang 1996), which is the W-rich analogue of hemusite $\left(\mathrm{Cu}_{4}^{+} \mathrm{Cu}^{2+}{ }_{2} \mathrm{Mo}^{4+} \mathrm{Sn}^{4+} \mathrm{S}_{8}\right.$ : Terziev 1971, Shimizu et al. 1991).

Molybdenite is isotypic with tungstenite, and these sulfides occur as hexagonal and trigonal polytypes, $2 \mathrm{H}$ and $3 R$ (e.g., Gait \& Mandarino 1970). The strong structural similarities would seem to favor a solid solution between molybdenite and tungstenite. In fact, a complete series between the hexagonal disulfides of Mo and W can be synthesized (Moh \& Udubaşa 1976). Yet in spite of a thorough search of the literature, we were unable to find well-documented reports of a solid solution between molybdenite and tungstenite. Only Höll \& Weber-Diefenbach (1973) reported the existence of a molybdenite-tungstenite solid solution, as extremely fine $(25 \times 2 \mu \mathrm{m})$ inclusions in scheelite from the Felbertal deposit in Austria. A strong interference from the W-rich host would be expected in analytical work on such minute domains, especially considering the electron-microprobe facility available twenty-five years ago. Furthermore, the minor amounts of tungsten ( 0.7 wt.\% W: Graeser 1964) and titanium (2 wt.\% Ti; cited in Newberry 1979) reported in the bulk compositions of molybdenite in the literature could well be due to microinclusions of $\mathrm{W}$ - or Ti-rich phases.
Tungstenoan Molybdenite in the Khibina Complex

The Khibina alkaline complex is a huge $\left(1327 \mathrm{~km}^{2}\right)$ concentrically zoned intrusive body of Devonian age, emplaced into Archean granitic gneiss, at its contact with Proterozoic volcanic and sedimentary complexes (e.g., Arzamastsev 1994, Kogarko et al. 1995). It consists of various silica-undersaturated igneous rocks and an aureole of hornfelses and fenites. In addition, an extensive zone over $20 \mathrm{~km}$ in strike length (Fig. 1) of scattered fenitized xenoliths of variable size and shape has been documented in the central part of the complex (Men'shikov 1978, Barkov et al. 2000). These may represent a string of foundered and metasomatized roofpendants.

The tungstenoan molybdenite occurs in a nephelineand perthite-rich fenite megaxenolith hosted by nepheline syenite (foyaite). Occurrences of Ti-bearing sulfides and a $\mathrm{Nb}$-rich sulfide, edgarite, have recently been reported from this xenolith (Barkov et al. 1997, 2000). The tungstenoan molybdenite characterized in this study occurs in a sample consisting predominantly of fine-grained nepheline ( $c a .70-80$ modal \%) that is partly replaced by a member of the sodalite group. Pyrrhotite (Ti-V-free), which is partly replaced by marcasite or pyrite (or both), occurs in subordinate amounts (up to $c a .5$ modal \%); chalcopyrite and galena are very rare. Neighborite, $\mathrm{NaMgF}_{3}$, occurs as small $(<0.1 \mathrm{~mm})$, typically roundish grains present in the same polished sections, though not in immediate contact with the molybdenite.

The tungstenoan molybdenite is present as (1) euhedral, compositionally zoned crystals $50-60 \mu \mathrm{m}$ in length, isolated within pyrrhotite or associated with marcasite (or pyrite, or both) (Figs. 2, 3), and (2) veinlets between and across silicate minerals (Fig. 4). The zoning in molybdenite is optically not obvious, and is best recognized by scanning-electron microscopy and electron-microprobe analysis.

\section{Analytical Method}

The molybdenite was analyzed by electron microprobe in wavelength-dispersion spectrometry mode (WDS) at McGill University. The analyses were carried out with a fully automated JEOL JXA-8900 electron microprobe, operated at $20 \mathrm{kV}$ and $30 \mathrm{nA}$. A finely focused beam was used for all the analyses. The following X-ray lines (and standards) were used: $M o L \beta$ (synthetic $\left.\mathrm{CaMoO}_{4}\right), \mathrm{W} L \alpha\left(\mathrm{CaWO}_{4}\right)$, and $K \alpha$ for $\mathrm{S}$ and $\mathrm{Fe}$ (pyrite). Counting times on peaks were 20 to $50 \mathrm{~s}$, and background measurement times above and below peaks were $25 \mathrm{~s}$ for $\mathrm{W}$ and $10 \mathrm{~s}$ for the other elements. The results were processed by a ZAF (JEOL) on-line program. An empirical correction for overlap between the $\mathrm{S} K \alpha$ and $\mathrm{MoL} \alpha$ emission lines was made. The minimum detection limit for $\mathrm{W}$ was $0.07 \mathrm{wt} . \%$. The precision of 


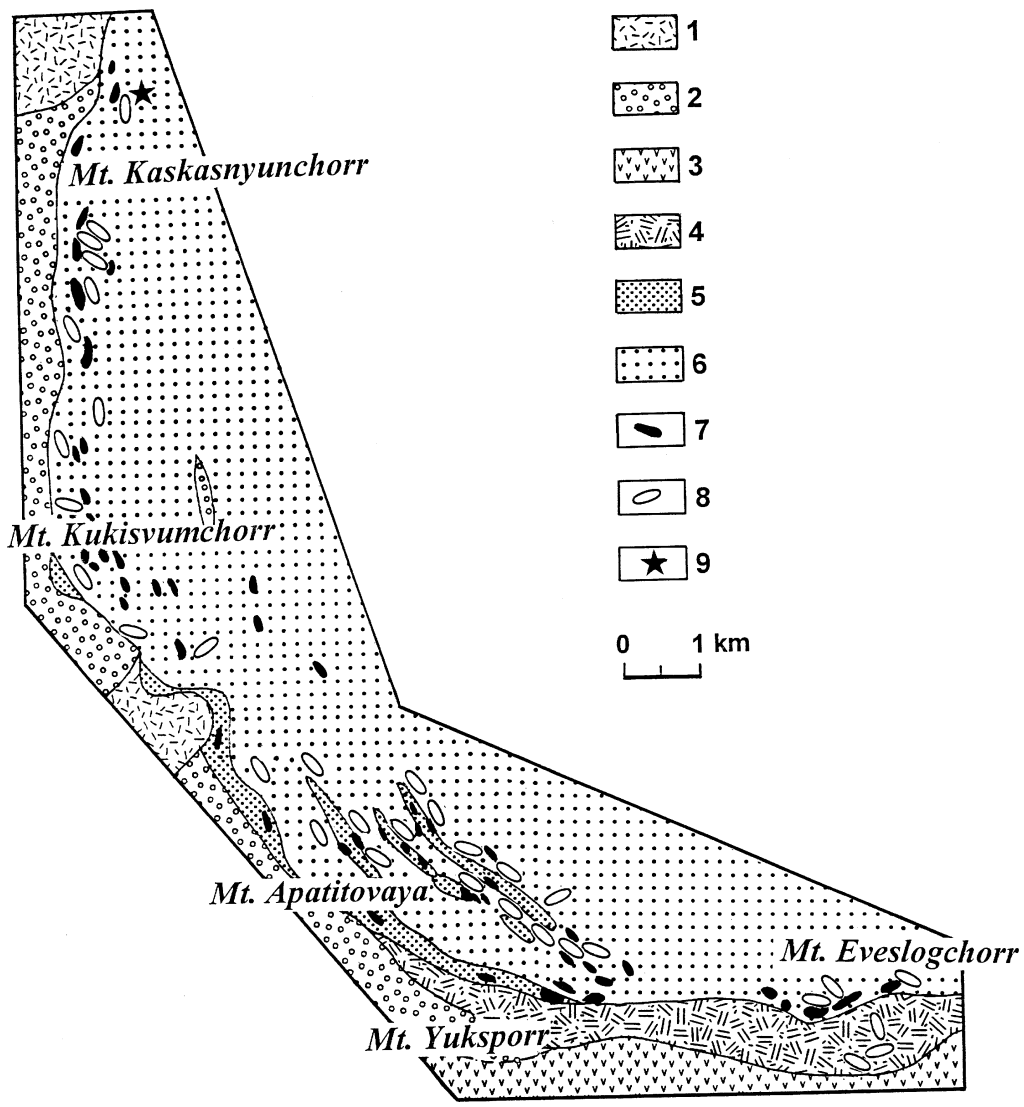

FIG. 1. Schematic geological map showing distribution of fenitized xenolithic bodies in the central part of the Khibina complex (Men'shikov, unpubl. map). 1: massive lyavochorrite, 2: massive rischorrite, 3 : foliated rischorrite, 4 : foliated and recrystallized nepheline syenite, 5: fine-grained nepheline syenite, 6: albitized trachytic foyaite, 7: fenitized xenoliths, 8: pegmatitic alkaline veins (not to scale), and 9: location of the xenolith containing tungstenoan molybdenite.

the analytical results, listed in Table 1 , is $\pm 0.5 \mathrm{wt} . \%$ for Mo, \pm 0.1 wt. $\%$ for $\mathrm{W}$, and \pm 0.25 wt. $\%$ for $\mathrm{S}$.

\section{COMPOSITION}

The results correspond well to the stoichiometry of tungstenoan molybdenite, (Mo,W) $\mathrm{S}_{2}$ (Table 1). There is a strong negative correlation between Mo and W (correlation coefficient $R=-0.92, n=25$; Fig. 5), indicating a homovalent substitution involving these elements. In view of the platy habit and small grain-size of the molybdenite, the minor Fe reported (Table 1) may have resulted, at least in part, from interference from nearby pyrrhotite or marcasite. Lower totals observed in some cases may be due to a variable thickness of the grains or their porous surface.
The highest W content (5.85 wt.\% W; 0.05 atoms of $\mathrm{W}$ per formula unit, apfu) is found in the central areas (5-6 $\mu \mathrm{m}$ wide) of the zoned crystals, which, owing to a higher mean atomic number, appear light in back-scattered electron images (Figs. 2a, b). The partly "corroded" shape of the W-rich zone in the center is noteworthy (Fig. 3b). Borders between the W-rich and W-poor zones are characteristically sharp, as illustrated by a detailed electron-microprobe traverse, for example (Fig. 6).

The molybdenite veinlets (Fig. 4a), some of which contain fibrous crystals (Fig. 4b), show exceptionally strong compositional variations. The content of $\mathrm{W}$ varies from below the limit of detection to $5.8 \mathrm{wt} . \% \mathrm{~W}$ in the internal zone of a composite veinlet (Fig. 4b; light zone). The adjacent area (Fig. 4b; dark zone) is rela- 


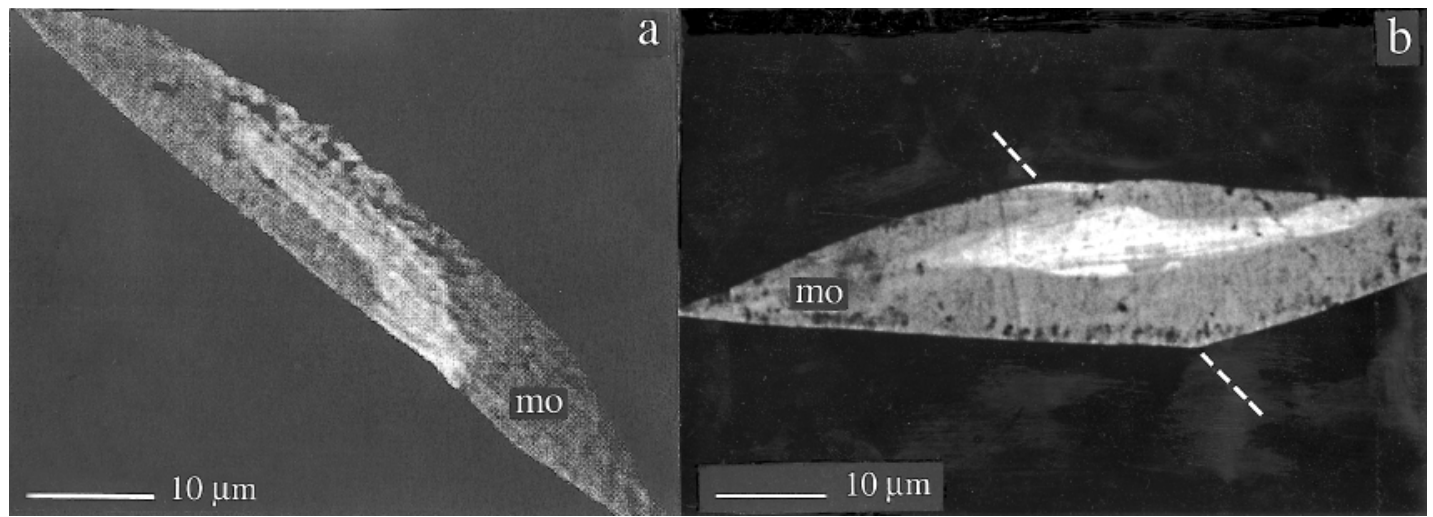

FIG. 2. Crystals of tungstenoan molybdenite (mo), enclosed within secondary marcasite after pyrrhotite (a) and within pyrrhotite (b). Note the W-rich zones (white) within these crystals. Back-scattered electron images. The dashed line across the crystal (shown in Fig. 2b) indicates location of traverse with quantitative electron-microprobe analyses (see Fig. 6).

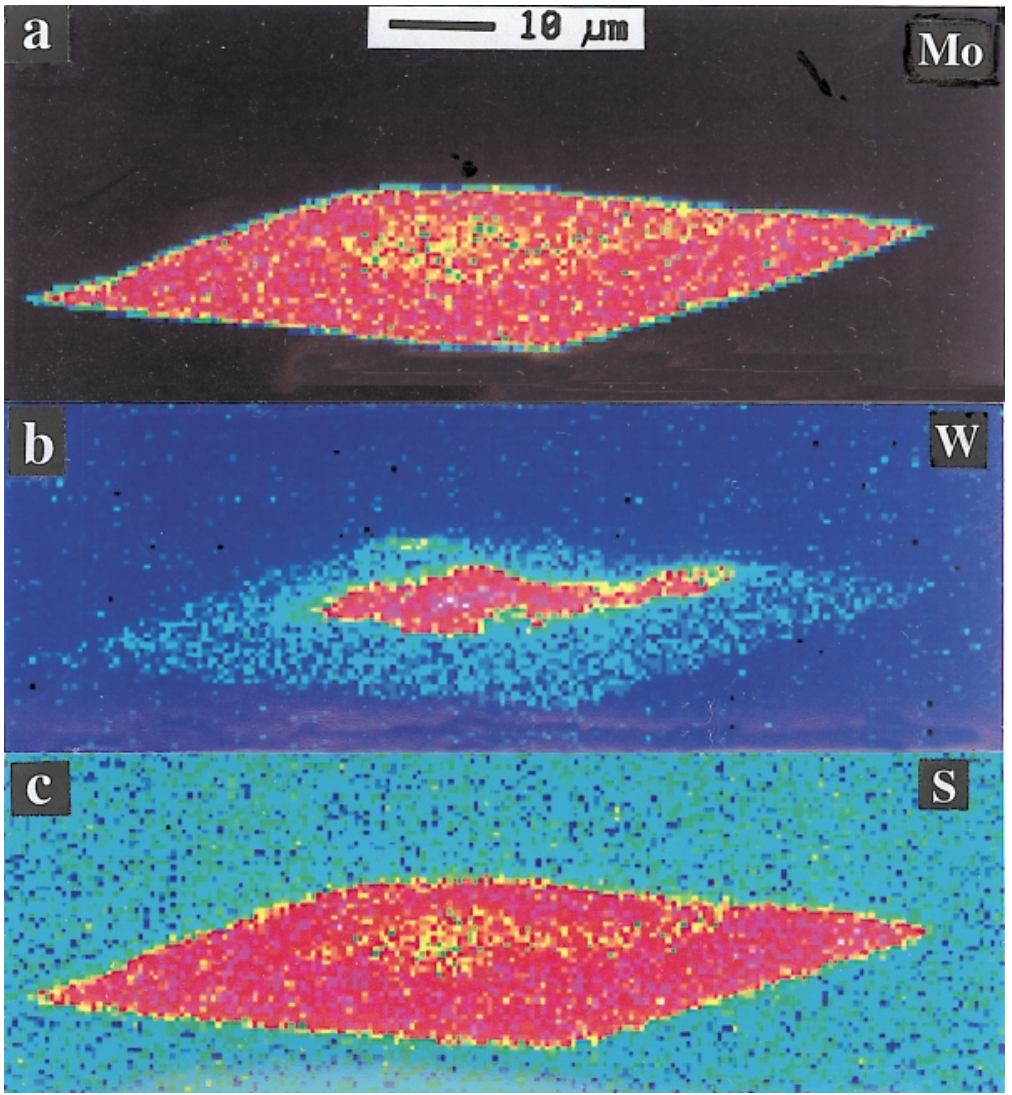

FIG. 3. X-ray maps of the zoned crystal of tungstenoan molybdenite (shown in Fig. 2b) for molybdenum (a), tungsten (b), the W-rich zone being shown in red, and sulfur (c). The thin blue outer zone in (a) is considered an artifact. 


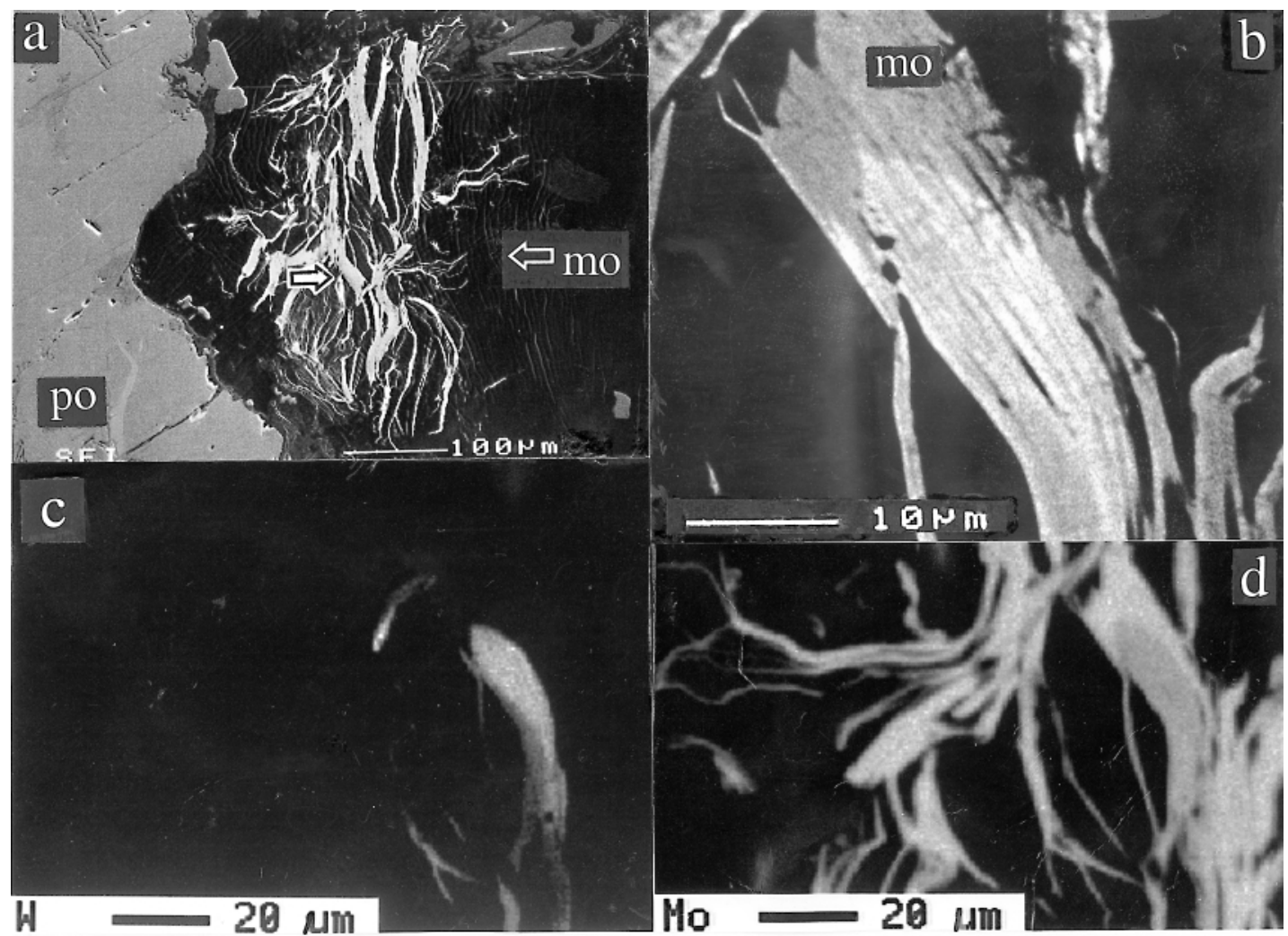

FIG. 4. a) Abundant veinlets of molybdenite (mo) among silicate minerals (black), near a large grain of pyrrhotite (po). Secondary electron image. Arrow in the center shows location of a zoned veinlet (fibrous crystal) of W-bearing molybdenite (mo; Fig. 4b); the W-rich zone is light-colored. Back-scattered electron image. c) and d) Tungsten and molybdenum X-ray maps, respectively, of the zoned veinlet of molybdenite shown in Figure 4b.

tively depleted in W: 1.2 wt.\%. In general, the W-rich zones exhibit a veinlet-like morphology, displayed by an X-ray map for W (Fig. 4c). The maximum concentrations of tungsten in the central zone of the zoned crystal (Fig. 2b) and in the W-rich zone of the composite veinlet (Fig. 4b) are identical (5.85 and 5.83 wt.\% W, respectively).

The WDS electron-microprobe analysis of the associated neighborite gave $\mathrm{Na} 23.66, \mathrm{~K} 0.11, \mathrm{Mg} 24.46, \mathrm{~F}$ 50.56 , sum of 98.79 wt.\%; the empirical formula is $\left(\mathrm{Na}_{1.16} \mathrm{~K}_{<0.01}\right) \mathrm{Mg}_{1.13} \mathrm{~F}_{3}$.

\section{DisCUSSION}

The apparent lack of $\mathrm{W}^{4+}$ in molybdenite in all previously described occurrences, as well as in hemusite, probably results from crystallization in an environment that is too strongly oxidizing, rather than for a structural reason. At Khibina, there are clear signs that a strongly reducing environment existed locally in the fenite. For example, the highly unusual presence of titanian pyrrhotite and marcasite is noteworthy, in which the titanium could be a mixture of $\mathrm{Ti}^{3+}$ and $\mathrm{Ti}^{4+}$ (Barkov et al. 1997). In addition, the new mineral species edgarite, $\mathrm{FeNb}_{3} \mathrm{~S}_{6}$, is inferred to contain a mixture of $\mathrm{Nb}^{3+}$ and $\mathrm{Nb}^{4+}$ (rather than the usual $\mathrm{Nb}^{5+}$ ), by analogy with structural findings on the synthetic equivalent (Barkov et al. 2000). Furthermore, the fenitized xenolith at Khibina contains spherules of a graphite-like phase. The occurrence of ferroan alabandite $\left(\mathrm{Mn}_{0.87-0.90} \mathrm{Fe}_{0.12-0.09} \mathrm{~S}_{1.0}\right)$ and an unusual $\mathrm{Mn}-(\mathrm{Fe})$-rich wurtzite- $2 H\left(\mathrm{Zn}_{0.47} \mathrm{Mn}_{0.27}\right.$ $\mathrm{Fe}_{0.26} \mathrm{~S}_{1.0}$; Barkov et al. 2000) also is consistent with a reduced environment.

The presence of tungstenoan molybdenite in the core zone of euhedral crystals and veinlets points to an early stage of metasomatism in which $f\left(\mathrm{O}_{2}\right)$ conditions were in the field of stability of the $\mathrm{W}^{4+}$ ion. Both molybdenum and tungsten were present in the reducing microenvironment at Khibina as ionic complexes in the fluid phase, which became saturated in molybdenite. We sug- 


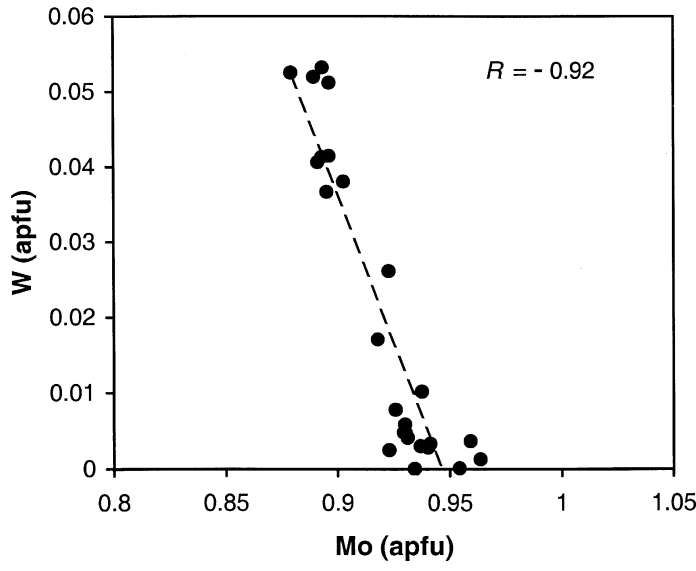

FIG. 5. Compositional variation of tungstenoan molybdenite from a fenite at Khibina. Plot of Mo versus W (atoms per formula unit, $a p f u ; \Sigma$ atoms $=3$ ).

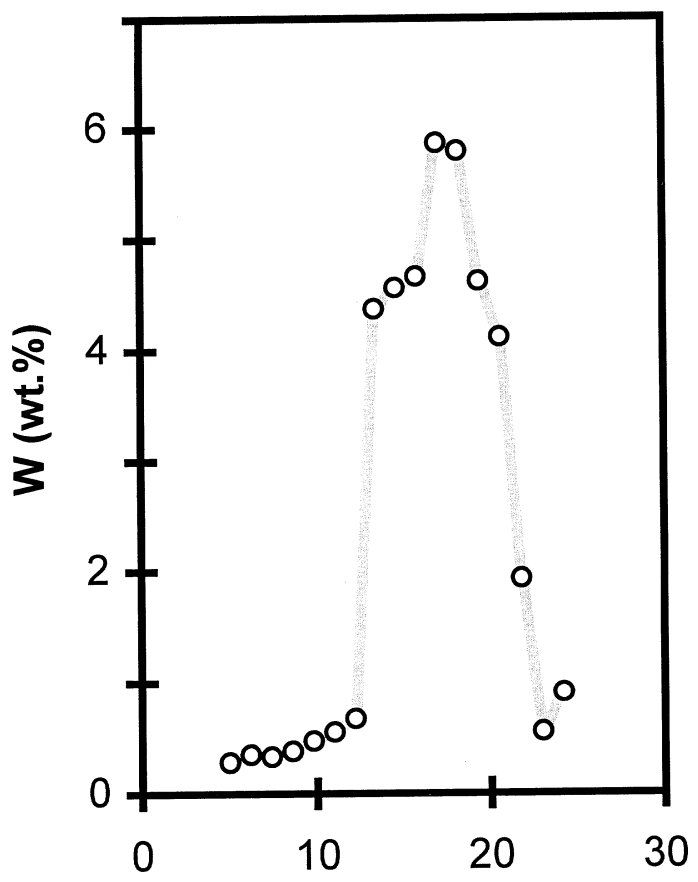

Distance in micrometers

FIG. 6. Electron-microprobe traverse for tungsten (in wt.\%) across the zoned crystal of tungstenoan molybdenite (see Fig. $2 b$ for location of this traverse).
TABLE 1. ELECTRON-MICROPROBE DATA ON TUNGSTENOAN MOLYBDENITE FROM THE KHIBINA COMPLEX

\begin{tabular}{|c|c|c|c|c|c|c|c|c|c|}
\hline \multirow[t]{2}{*}{ No. } & Mo & W & $\mathrm{Fe}$ & $\mathrm{S}$ & Total & Mo & W & $\mathrm{Fe}$ & $\mathrm{S}$ \\
\hline & \multicolumn{5}{|c|}{ Results of analyses (wt.\%) } & \multicolumn{4}{|c|}{ Proportions of atoms ( $a p f u$ ) } \\
\hline 1 & 51.31 & 5.85 & 0.34 & 39.20 & 96.70 & 0.89 & 0.05 & 0.01 & 2.04 \\
\hline 2 & 53.35 & 5.83 & 1.05 & 40.22 & 100.45 & 0.90 & 0.05 & 0.03 & 2.02 \\
\hline 3 & 51.88 & 5.80 & 1.06 & 39.50 & 98.24 & 0.89 & 0.05 & 0.03 & 2.03 \\
\hline 4 & 52.55 & 4.66 & 1.00 & 39.83 & 98.04 & 0.90 & 0.04 & 0.03 & 2.03 \\
\hline 5 & 52.16 & 4.62 & 1.14 & 39.65 & 97.57 & 0.89 & 0.04 & 0.03 & 2.03 \\
\hline 6 & 52.23 & 4.56 & 0.97 & 39.94 & 97.70 & 0.89 & 0.04 & 0.03 & 2.04 \\
\hline 7 & 54.15 & 4.37 & 0.98 & 40.72 & 100.22 & 0.90 & 0.04 & 0.03 & 2.03 \\
\hline 8 & 52.50 & 4.12 & 1.19 & 39.84 & 97.65 & 0.90 & 0.04 & 0.03 & 2.03 \\
\hline 9 & 54.61 & 2.96 & 0.09 & 40.49 & 98.15 & 0.92 & 0.03 & $<0.01$ & 2.05 \\
\hline 10 & 54.18 & 1.93 & 1.17 & 40.05 & 97.33 & 0.92 & 0.02 & 0.03 & 2.03 \\
\hline 11 & 56.16 & 1.17 & 0.24 & 40.94 & 98.51 & 0.94 & 0.01 & $<0.01$ & 2.05 \\
\hline 12 & 55.79 & 0.67 & 0.98 & 40.82 & 98.26 & 0.93 & 0.006 & 0.03 & 2.04 \\
\hline 13 & 56.13 & 0.55 & 0.98 & 41.06 & 98.72 & 0.93 & 0.005 & 0.03 & 2.04 \\
\hline 14 & 55.93 & 0.47 & 1.00 & 40.86 & 98.26 & 0.93 & 0.004 & 0.03 & 2.04 \\
\hline 15 & 58.77 & 0.43 & 1.31 & 40.94 & 101.45 & 0.96 & 0.004 & 0.04 & 2.00 \\
\hline 16 & 56.43 & 0.38 & 1.02 & 40.60 & 98.43 & 0.94 & 0.003 & 0.03 & 2.03 \\
\hline 17 & 56.83 & 0.33 & 1.05 & 40.95 & 99.16 & 0.94 & 0.003 & 0.03 & 2.03 \\
\hline 18 & 58.35 & 0.14 & 0.07 & 41.13 & 99.69 & 0.96 & 0.001 & $<0.01$ & 2.03 \\
\hline
\end{tabular}

Note: 1 veinlet in silicate, center; 11 the same veinlet, periphery (light and dark zones in Fig. 4b); 2 to 8 euhedral crystal, centre (Fig. 2b, white); 10 and 12 to 17 the same crystal, periphery (Fig. 2b, gray); 9 a veinlet in silicate (center); 18 thin veinlet in silicate. Rhenium was sought, but not detected. The analytical results are listed in order of decreasing content of $\mathrm{W}$. The proportions of atoms are quoted in atoms per formula unit $(a p f u) . \Sigma$ atoms $=3$.

gest that the early formation of molybdenite took place somewhat below the $\mathrm{WO}_{2}-\mathrm{WO}_{3}$ buffer (or the $\mathrm{WO}_{2}-$ $\mathrm{WO}_{2.72}$ buffer above $600^{\circ} \mathrm{C}$ : Cygan \& Chou 1990). Under these conditions, the $\mathrm{W}^{4+}$ ion was available for incorporation in the growing crystals of molybdenite. Interestingly, the hydrothermal mobility of tungsten seems significantly enhanced in such a low- $f\left(\mathrm{O}_{2}\right)$ environment. Wood \& Vlassopoulos (1989) found this to be the case in a study of speciation of tungsten at $500^{\circ} \mathrm{C}$ and $1 \mathrm{kbar}$, conditions that are probably realistic for the early fenitization of the xenoliths. They found that about three times more tungsten can be held in solution as the tungstenoan complex at this temperature and pressure than would be the case in the field of stability of the tungstenian complex at a fugacity of oxygen above the relevant buffer curve.

To continue with our reconstruction of the events that gave rise to the zoned crystals of molybdenite, we suggest that $f\left(\mathrm{O}_{2}\right)$ was generally increasing in the environment of growth. The cores of the euhedral crystals of tungstenoan molybdenite were partly resorbed in the more oxygenated fluid (e.g., Fig. 3b), and the peripheral zones poorer in $\mathrm{W}$ formed. As the buffer curve was crossed, molybdenite devoid of tungsten continued to grow, as $\mathrm{W}^{6+}$ complexes became predominant in the fluid medium. Presumably, beyond this point, any tungsten-bearing phase likely to form from this fenitizing fluid was a tungstate, or perhaps a peralkaline silicate like khomyakovite or manganokhomyakovite, newly 


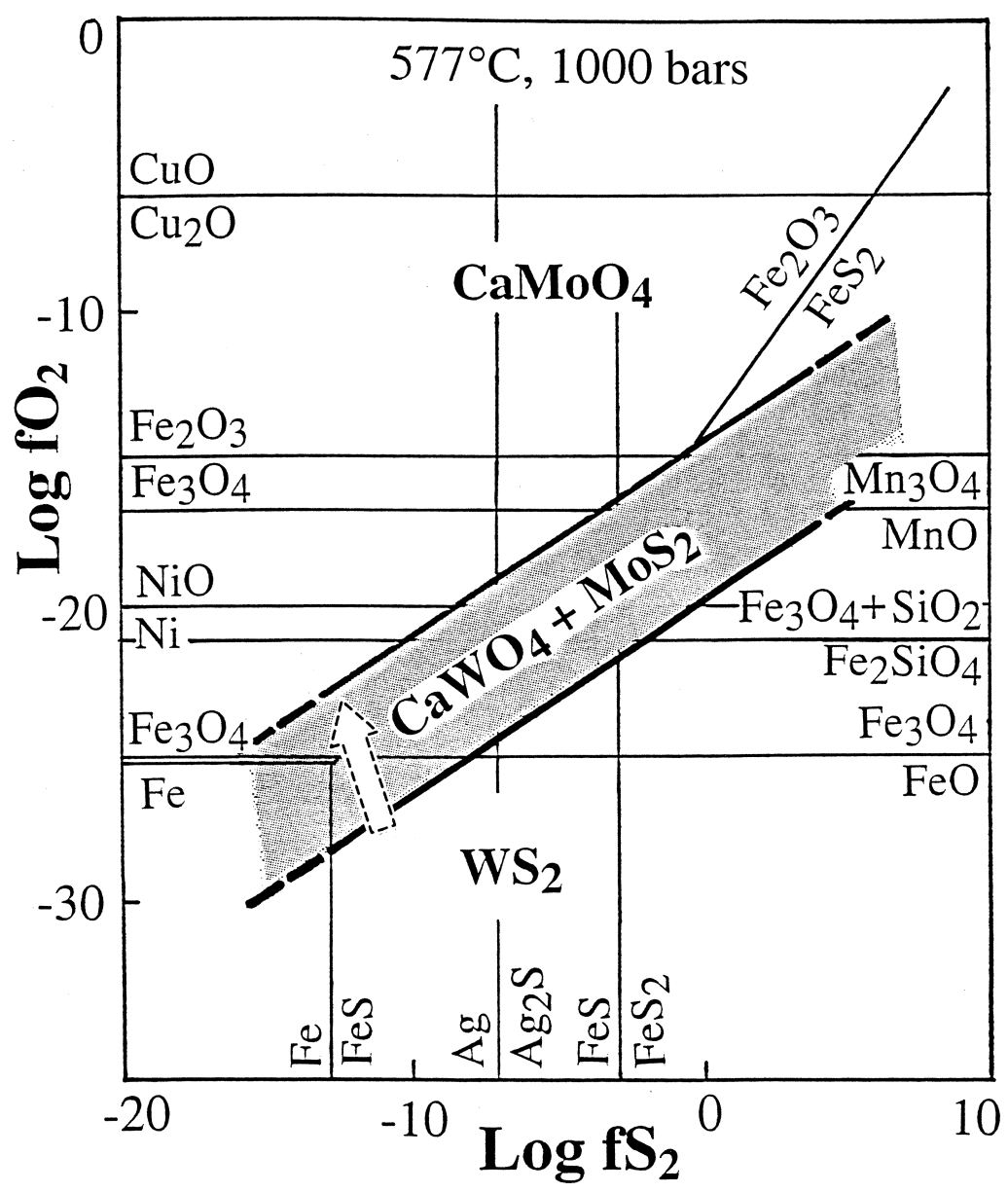

FIG. 7. A plot of $\log f\left(\mathrm{~S}_{2}\right)$ versus $\log f\left(\mathrm{O}_{2}\right)$ showing the stability field of molybdenite and scheelite relative to tungstenite $\left(\mathrm{WS}_{2}\right)$ (modified from Hsu 1977).

discovered tungsten-bearing eudialyte-group minerals in which $\mathrm{W}^{6+}$ occupies the $\mathrm{Nb}^{5+}$ site (Johnsen et al. 1999).

In a low- $f\left(\mathrm{O}_{2}\right)$ environment, at elevated fugacity of sulfur, elements normally of lithophile character can take on a chalcophile character. This tendency is well displayed in the behavior of $\mathrm{Ti}, \mathrm{Cr}, \mathrm{V}, \mathrm{Ca}, \mathrm{Mn}$, and $\mathrm{Mg}$ in meteorites (Keil \& Andersen 1965, Keil 1968, Keil \& Brett 1973, Okada \& Keil 1982, Armstrong et al. 1985). At the same level of sulfur fugacity, tungstenite, $\mathrm{WS}_{2}$, forms at a lower $f\left(\mathrm{O}_{2}\right)$ than molybdenite (Hsu 1977). With an increase in $f\left(\mathrm{O}_{2}\right)$ and a decrease in $f\left(\mathrm{~S}_{2}\right)$, the common assemblage molybdenite + scheelite is stabilized at the expense of molybdenite + tungstenite. The likely evolutionary path indicated by the dashed arrow in Figure 7, a plot of $\log f\left(\mathrm{O}_{2}\right)$ versus $\log f\left(\mathrm{~S}_{2}\right)$, is positioned in the field of stability of pyrrhotite, but close to the field of stability of native iron. The presence of native iron has been documented by X-ray diffraction and electron-microprobe analysis in other samples of fenite from the Khibina complex (Men'shikov, unpubl. data).

Such reducing conditions could well be due to the presence of a hydrocarbon-rich fluid in the environment. Elevated concentrations of hydrocarbons are involved in the formation of secondary minerals at Khibina (Karzhavin 1974). Occurrences of bitumen (Pripachkin et al. 1985) and methane inclusions of secondary origin (Potter et al. 1998) were reported from the Khibina suite. One way to account for the presence of hydrocarbons is to appeal to the Fischer-Tropsch reaction (e.g., Salvi \& Williams-Jones 1997). The graphite-like phase associated with the tungstenoan molybdenite may have precipitated from such a fluid by the reaction $\mathrm{CH}_{4}+\mathrm{CO}_{2}=$ $2 \mathrm{C}+2 \mathrm{H}_{2} \mathrm{O}$.

The late increase in $f\left(\mathrm{O}_{2}\right)$ in the system is considered to have resulted in the formation of the W-poor molybdenite; this increase could be due to degassing and pref- 
erential loss of hydrogen at Khibina, but other hypotheses also are viable. An influx of an external fluid phase could have resulted in a sudden rise in $f\left(\mathrm{O}_{2}\right)$ above the $\mathrm{WO}_{2}-\mathrm{WO}_{3}$ buffer into the domain of $\mathrm{W}^{6+}$; dilution of the earlier fluid and a net loss of alkalis, leading to the development of strongly peraluminous bulk compositions, could also be consequences of this late influx.

In addition, variations in sulfur fugacity may have played a role. According to experimental and thermodynamic data, the formation of $\mathrm{WS}_{2}$ requires a higher $f\left(\mathrm{~S}_{2}\right)$ than the formation of $\mathrm{MoS}_{2}$; the $\mathrm{MoS}_{2}-\mathrm{Mo}_{2} \mathrm{~S}_{3}$ buffer curve is located below the FeS - Fe buffer, and the $\mathrm{WS}_{2}-\mathrm{W}$ buffer curve is located above the $\mathrm{FeS}-\mathrm{Fe}$ buffer (Štemprok 1971, Fegley \& Palme 1985, Palme et al. 1994, and references therein). The relative position of these buffers thus suggests that the W-rich molybdenite crystallized at a sulfur fugacity higher than that at which the $\mathrm{W}$-poor molybdenite crystallized. The zoning patterns in the molybdenite at Khibina may thus also reflect a general decrease of $f\left(\mathrm{~S}_{2}\right)$ in the fluid (Fig. 7).

\section{ACKNOWLEDGEMENTS}

Research costs were covered by a grant from the Natural Sciences and Engineering Research Council of Canada to the second author. Helpful reviews from Yuanming Pan, R. Gieré and Associate Editor R.H. Mitchell are appreciated.

\section{REFERENCES}

Armstrong, J.T., El-Goresy, A. \& WASSERbURG, G.J. (1985): Willy: a prize noble Ur-Fremdling - its history and implications for the formation of fremdlinge and CAI. Geochim. Cosmochim. Acta 49, 1001-1022.

Arzamastsev, A.A. (1994): Unique Paleozoic Intrusions of the Kola Peninsula. Kola Science Center, Russian Academy of Sciences, Apatity, Russia.

BARKov, A.Y., LAAJOKI, K.V.O., MEN'ShIKOV, Y.P., AlAPIETI, T.T. \& SivONEN, S.J. (1997): First terrestrial occurrence of titanium-rich pyrrhotite, marcasite and pyrite in a fenitized xenolith from the Khibina alkaline complex, Russia. Can. Mineral. 35, 875-885.

Martin, R.F., Men'shikov, Y.P., SAVChenKo, Y.E., Thibault, Y. \& LAajoKI, K.V.O. (2000): Edgarite, $\mathrm{FeNb}_{3} \mathrm{~S}_{6}$, first natural niobium-rich sulfide from the Khibina alkaline complex, Russian Far North: evidence for chalcophile behavior of $\mathrm{Nb}$ in a fenite. Contrib. Mineral. Petrol. 138, 229-236.

Bernard, A., Symonds, R.B. \& Rose, W.I., JR. (1990): Volatile transport and deposition of Mo, W and Re in high temperature magmatic fluids. Appl. Geochem. 5, 317-326.

Cygan, G.L. \& Chou, I-Ming (1990): The assemblage $\mathrm{WO}_{2}+$ $\mathrm{H}_{2} \mathrm{O}$ as a steady-state hydrogen source in moderately reduced hydrothermal experiments. Am. Mineral. 75, 13991405 .
Fegley, B., JR. \& PAlme, H. (1985): Evidence for oxidizing conditions in the solar nebula from Mo and $\mathrm{W}$ depletions in refractory inclusions in carbonaceous chondrites. Earth Planet. Sci. Lett. 72, 311-326.

GAIT, R.I. \& MANDARINO, J.A. (1970): Polytypes of tungstenite. Can. Mineral. 10, 729-731.

GoLDSCHMIDT, V.M. (1954): Geochemistry. Oxford University Press. Oxford, U.K.

Graeser, S. (1964): Über Funde der neuen rhomboedrischen $\mathrm{MoS}_{2}$-Modification (Molybdänit-3R) und von Tungstenit in den Alpen. Schweiz. Mineral. Petrogr. Mitt. 44, 121-128.

Harris, D.C., Roberts, A.C., Thorpe, R.I., Criddle, A.J. \& STANLEY, C.J. (1984): Kiddcreekite, a new mineral species from the Kidd Creek mine, Timmins, Ontario and from the Campbell orebody, Bisbee, Arizona. Can. Mineral. 22, 227-232.

Höll, R. \& Weber-Diefenbach, K. (1973): Tungstenitemolybdenite solid-solution series from the scheelite deposit of Felbertal (Hohe Tauern, Austria). Neues Jahrb. Mineral., Monatsh., 27-34.

Hsu, L.C. (1977): Effects of oxygen and sulfur fugacities on the scheelite-tungstenite and powellite-molybdenite stability relations. Econ. Geol. 72, 664-670.

Johnsen, O., Gault, R.A., Grice, J.D. \& ERcit, T.S. (1999): Khomyakovite and manganokhomyakovite, two new members of the eudialyte group from Mont Saint-Hilaire, Quebec, Canada. Can. Mineral. 37, 893-899.

KARZHAVIN, V.K. (1974): Hydrocarbon gases of the Khibina massif and their relation to the alkaline component of minerals and rocks. In Alkaline Rocks of the Kola Peninsula (T.N. Ivanova, ed.). Nauka, Leningrad, Russia (80-85; in Russ.).

KeIL, K. (1968): Mineralogical and chemical relationships among enstatite chondrites. J. Geophys. Res. 73, 6945-6976.

\& ANDERSEN, C.A. (1965): Electron microprobe study of the Jajh deh Kot Lalu enstatite chondrite. Geochim. Cosmochim. Acta 29, 621-632.

\& BretT, R. (1973): Heideite, $(\mathrm{Fe}, \mathrm{Cr})_{1+\mathrm{x}}(\mathrm{Ti}, \mathrm{Fe})_{2} \mathrm{~S}_{4}$, a new mineral in the Bustee enstatite achondrite. Meteoritics 8, 48-49 (also Am. Mineral. 59, 465-470, 1974).

Kogarko, L.N., Kononova, V.A., Orlova, M.P. \& WoOlley, A.R. (1995): The Alkaline Rocks and Carbonatites of the World. II. Former USSR. Chapman \& Hall, London, U.K.

KovalEnKER, V.A., LAPUTINA, I.P. \& VyAL'sov, L.N. (1974): Rhenium-rich molybdenite from the Talnakh coppernickel deposit (Noril'sk region). Dokl. Acad. Sci. USSR, Earth Sci. Sect. 217, 104-106.

Men'shikov, Y.P. (1978): Corundum mineralization in the Khibina alkaline complex. Dokl. Akad. Nauk SSSR 243, 1247-1249 (in Russ.). 
MoH, G.H. \& UdubAŞA, G. (1976): Molybdenite-tungstenite solid solution series and phase relations in the Mo-W-S system. Chem. Erde 35, 327-335.

NewberRy, R.J.J. (1979): Polytypism in molybdenite (I): a non-equilibrium impurity-induced phenomenon. Am. Mineral. 64, 758-767.

OKADA, A. \& KeIL, K. (1982): Caswellsilverite, $\mathrm{NaCrS}_{2}$ : a new mineral in the Norton County enstatite achondrite. Am. Mineral. 67, 132-136.

Palme, H., Hutcheon, I.D. \& Spettel, B. (1994): Composition and origin of refractory-metal-rich assemblages in a $\mathrm{Ca}, \mathrm{Al}$-rich Allende inclusion. Geochim. Cosmochim. Acta 58, 495-513.

Potter, J., Rankin, A.H., Treloar, P.J., Nivin, V.A., Ting, WUPAO \& Ni, PEI (1998): A preliminary study of methane inclusions in alkaline igneous rocks of the Kola igneous province, Russia: implications for the origin of methane in igneous rocks. Eur. J. Mineral. 10, 1167-1180.

Pripachkin, V.A., Pavlova, M.A., Galakhova, T.N., Volokhova, T.S. \& MalashKINA, V.T. (1985): Bitumens of the Khibina carbonatites. Dokl. Akad. Nauk SSSR 281, 1424-1426 (in Russ.)

Salvi, S. \& Williams-Jones, A.E. (1997): Fischer-Tropsch synthesis of hydrocarbons during subsolidus alteration of the Strange Lake peralkaline granite, Quebec/Labrador, Canada. Geochim. Cosmochim. Acta 61, 83-99.
Shimizu, M., Stanley, C.J., Criddle, A.J., Kato, A. \& Matsubara, S. (1991): New compositional and optical data for antimonian and bismuthian varieties of hemusite from Japan. Mineral. Petrol. 45, 11-17.

ŠTEMPROK, M. (1971): The iron - tungsten - sulphur system and its geological application. Mineral. Deposita 6, 302312.

Terziev, G.I. (1971): Hemusite - a complex copper - tin molybdenum sulfide from the Chelopech ore deposit, Bulgaria. Am. Mineral. 56, 1847-1854.

Wood, S.A. \& Vlassopoulos, D. (1989): Experimental determination of the hydrothermal solubility and speciation of tungsten at $500^{\circ} \mathrm{C}$ and $1 \mathrm{kbar}$. Geochim. Cosmochim. Acta 53, 303-312.

Zhang, S. \& Zhang, L. (1996): The first discovery of $\mathrm{Cu}_{6} \mathrm{SnWS}_{8}$ in China. Acta Mineral. Sinica 16, 257-259 (in Chinese).

Received March 13, 2000, revised manuscript accepted October 25, 2000. 
